Vol. 18 (2009): 27-34.

\title{
Effects of L-carnitine and iron diet supplementations on growth performance, carcass characteristics and blood metabolites in fattening pigs
}

Arkadiusz Pietruszka*, Eugenia Jacyno, Anita Kołodziej, Maria Kawęcka, Czesław Elzanowski and Beata Matysiak

Department of Pig Breeding, Agricultural University of Szczecin, Doktora Judyma 10 st., 71-460 Szczecin, Poland

*e-mail: Arkadiusz.Pietruszka@biot.ar.szczecin.pl

The aim of this study was to evaluate the effect of dietary L-carnitine supplementation either with or without extra $\mathrm{Fe}$ supplementation from $\mathrm{Fe}$-amino acid (Fe-AA) complex on body weight gain, feed conversion, carcass characteristics and blood metabolite concentrations in fattening pigs. The study was carried out with 75 fatteners (30-100 kg body weight), divided into three groups, of 25 pigs each. The control group was given a basal diet that contained $85 \mathrm{mg} / \mathrm{kg}$ of Fe from premix. A L-carnitine group was given a basal diet supplemented with $100 \mathrm{mg} / \mathrm{kg}$ of L-carnitine, and a L-carnitine $+F e$ group was given a basal diet supplemented with $100 \mathrm{mg} / \mathrm{kg}$ of L-carnitine and $60 \mathrm{mg} / \mathrm{kg}$ of Fe from a Fe-AA complex. The supplement of L-carnitine to the diets did not have any effects on the growth performance and carcass traits. The L-carnitine supplement decreased the concentration of triglycerides $(p \leq 0.05)$, cholesterol $(p \leq 0.05)$ and low-density lipoproteins $(p$ $\leq 0.01)$ in the blood serum of pigs, while it increased $(p \leq 0.01)$ the concentration of high-density lipoproteins. The combination of L-carnitine $+\mathrm{Fe}$ increased the growth performance of growing pigs $(p \leq 0.05)$ and the lean percentage and fatless ham weight in carcass and also increased $(p \leq 0.05)$ the Fe content in the blood serum and the longissimus dorsi muscle of pigs. The results suggest the more effective outcomes can be reached when L-carnitine+Fe rather than only L-carnitine is used in diets.

Key-words: L-carnitine, iron, fatteners, growth performance, blood metabolites 
Pietruszka, A. et al. Effects of L-carnitine and iron on pig's traits

\section{Introduction}

L-carnitine is a vitamin-like compound that is necessary for the transportation of long-chain fatty acids across the inner mitochondrial membrane for $\beta$-oxidation (Hoppel 2003). It can be synthesized in the body from protein-bound lysine and methionine. In addition, several cofactors are involved such as iron $\left(\mathrm{Fe}^{+2}\right)$, ascorbate, niacyn and vitamin $\mathrm{B}_{6}$ (Vaz and Wanders 2002).

The synthesis of L-carnitine in mammal organisms is insufficient, thus its requirement should be supplemented by feed ration. The amount of L-carnitine in plant feeds is small (5-29 mg/kg), while much larger quantities (at about $150 \mathrm{mg} / \mathrm{kg}$ ) are found in feeds of animal origin (Jacobs 2002). At present, pig diets are based first of all on plant components, thus the demand of pigs for L-carnitine might not be covered, and L-carnitine supplementation could be necessary. Studies have demonstrated the beneficial effects of L-carnitine supplementation on the reproductive performance of breeding sows and weaning of piglets (Eder et al. 2001, Ramanau et al. 2004) and the quality of boar semen (Währner et al. 2004, Jacyno et al. 2007).

In the studies on the effect of L-carnitine on the growth rate, feed conversion and the quality of pig carcasses, no clear results have been found (Owen et al. 2001a, 2001b, Rekiel and Zackiewicz 2004, Han and Thacker 2006). L-carnitine has a role in the metabolism of lipids, carbohydrates and some amino acids and thus can modify the concentration of metabolites in blood (Grela et al. 2005).

One of the most important functions of iron $(\mathrm{Fe})$ is to stimulate the blood-producing system to synthesize hemoglobin and myoglobin, as well as to participate in oxygen transportation by erythrocytes. The effect of iron on the growth rate, feed conversion and pig carcass quality is ambiguous. Dove and Haydon (1991) and Saddoris et al. (2003) found that pig diet supplementation with iron did not have any effect on the fattening results. In other studies, the positive effect of iron was observed on the daily gain in piglets (Rincker et al. 2004) and fatteners (Liao et al. 2005). Some studies also show that the supplementation of fatteners diet with $\mathrm{Fe}$ increases its content in meat and blood as well as positively affecting meat sensory quality (O'Sullivan et al. 2003, Liao et al. 2005, Apple et al. 2007).

Iron requirements have not been precisely established for pigs. According to the National Research Council (1998), iron requirements of growing pigs range between 40 and $100 \mathrm{mg} / \mathrm{kg}$. In the European Union, a differential level of iron in the feed for fatteners is used: $80-150$ for growing pigs, $65-110 \mathrm{mg} / \mathrm{kg}$ for finishing pigs (Lipiński 2007). According to Commission Regulation (No $1334 / 2003 / E C)$ the maximum content of iron can not exceed 750 (totally) $\mathrm{mg} / \mathrm{kg}$ of the complete feeding stuff.

The aim of this study was to determine the effect of L-carnitine and L-carnitine and iron supplementation of fattening pig diets on body weight gain, feed conversion, carcass characteristics and concentration of blood metabolites.

\section{Material and methods}

\section{Animals and feeding}

The study was carried out at production farm with 75 fatteners, hybrids after Polish Large White $\times$ Polish Landrace sows and Pietrain $\times$ Duroc and Pietrain $\times$ Hampshire boars. The same number of pigs with different sex, genotype and body weight were allotted to three treatments. There were 25 pigs in each treatment group. The animals were housed with litter in pens of five pigs. Feed was provided ad libitum and water was provided by nipple waterers.

The pigs were given grower base diets during the fattening period of $30-60 \mathrm{~kg}$ body weight and finisher types during the fattening period of 60-100 $\mathrm{kg}$ body weight. The basal diet met or exceeded NRC (1998) recommendations for nutrients (Table 1).

The basal diets contained a supplement of 85 $\mathrm{mg} / \mathrm{kg} \mathrm{Fe}$ (from premix). The factor distinguishing 
Vol. 18 (2009): 27-34.

Table1. Composition and nutritive value of basal grower and finisher diets.

\begin{tabular}{lcc}
\hline & Grower & Finisher \\
\hline Ingredients $(\mathrm{g} / \mathrm{kg})$ & 350 & 150 \\
Barley & 226 & 427.5 \\
Triticale & 150 & 150 \\
Wheat & 50 & 100 \\
Wheat bran & 120 & 53.5 \\
Soybean meal & 60 & 90 \\
Rapeseed meal & 15 & - \\
Soybean oil & 29 & 29 \\
Mineral, vitamin and amino acid premix ${ }^{\mathrm{a}}$ & & \\
Nutrients & 12.8 & 12.6 \\
Metabolisable energy $(\mathrm{MJ} / \mathrm{kg})$ & 177 & 156 \\
Crude protein $(\mathrm{g} / \mathrm{kg})$ & 32.0 & 32.9 \\
Crude fibre $(\mathrm{g} / \mathrm{kg})$ & 32.4 & 21.4 \\
Crude fat $(\mathrm{g} / \mathrm{kg})$ & 53.4 & 38.6 \\
Crude ash $(\mathrm{g} / \mathrm{kg})$ & 9.4 & 7.7 \\
Lysine $(\mathrm{g} / \mathrm{kg})$ & 6.1 & 5.1 \\
Methionine $+\mathrm{cystine}(\mathrm{g} / \mathrm{kg})$ & 6.6 & 5.4 \\
Threonine $(\mathrm{g} / \mathrm{kg})$ & 7.3 & 5.3 \\
Ca $(\mathrm{g} / \mathrm{kg})$ & 5.9 & 4.5 \\
P $(\mathrm{g} / \mathrm{kg})$ & 1.3 & 1.1 \\
Na $(\mathrm{g} / \mathrm{kg})$ & 85 & 85 \\
Fe from premix $(\mathrm{mg} / \mathrm{kg})$ & & \\
\hline
\end{tabular}

${ }^{\text {a }}$ The premix supplied the following per kg diet: Mn, $60 \mathrm{mg}$; Zn, $130 \mathrm{mg}$; Cu, $25 \mathrm{mg}$; I, $0.5 \mathrm{mg}$; Se, $0.3 \mathrm{mg}$; Fe, 85 mg (analyzed); vitamin A, $9000 \mathrm{IU}$; vitamin $\mathrm{D}_{3}, 1000 \mathrm{IU}$; vitamin E, $87.5 \mathrm{mg}$; vitamin $\mathrm{K}, 2 \mathrm{mg}$; vitamin $\mathrm{B}_{12} 25 \mu \mathrm{g}$; biotin, $25 \mu \mathrm{g}$; niacin, $20 \mathrm{mg}$; folic acid, $1 \mathrm{mg}$; choline chloride, $125 \mathrm{mg}$; pantothenic acid, $20 \mathrm{mg}$; lysine, $2.4 \mathrm{mg}$; methionine, $0.6 \mathrm{mg}$; threonine, $1.1 \mathrm{mg}$.

respective groups was the content of L-carnitine (Carniking ${ }^{\circledR}$; Lonza, Ltd, Basel, Switzerland) and $\mathrm{Fe}$ (from Fe-AA complex, Polfa Kutno, Ltd, Kutno, Poland) in the diets.

Pig fattening was carried out from 30 to 100 $\mathrm{kg}$ body weight. During this period, they were weighed three times: at the beginning of fattening, at a body weight of about $60 \mathrm{~kg}$, and before slaughter (at about $100 \mathrm{~kg}$ ). Average daily gain (ADG), average daily feed intake (ADFI), feed conver- sion (feed:gain ratio) were determined for all pigs throughout the experimented period.

\section{Slaughter value}

All pigs were slaughtered at $100 \mathrm{~kg}$ body weight. Carcasses were weighed immediately following slaughter, then chilled at $4{ }^{\circ} \mathrm{C}$ for $24 \mathrm{~h}$, and the right side was dissected. Carcass evaluation was conducted according to the Polish Pig Testing Stations methodology. 


\section{Pietruszka, A. et al. Effects of L-carnitine and iron on pig's traits}

Meat content was estimated as follow:

$\mathrm{y}=1.745 \mathrm{x}_{1}+0.836 \mathrm{x}_{2}+0.157 \mathrm{x}_{3}-1.884$

where:

$\mathrm{y}$ - weight of meat in right carcass side $(\mathrm{kg})$,

$\mathrm{x}_{1}$ - weight of fatless ham $(\mathrm{kg})$,

$\mathrm{x}_{2}$ - weight of longissimus muscle $(\mathrm{kg})$,

$\mathrm{x}_{3}-$ double width + height of the longissimus muscle $(\mathrm{cm})$.

For determining the content of $\mathrm{Fe}$, samples of the longissimus dorsi muscle were collected from the section between lumbar vertebra 2 and 4. Also blood samples were collected from the pigs during slaughter for biochemical analyses.

\section{Chemical analysis}

Basic nutrients in feeds were determined by standard methods (AOAC, 1995), while amino acids with a Beckman automatic analyser. Phosphorus (P) was assayed by the vanadium-molybdenum photocalorimetric method, whereas calcium $(\mathrm{Ca})$ and sodium $\mathrm{Na}$ through an emission spectrometry method on a BUCK Scientific spectrophotometer. The content of Fe in premix, Fe-AA complex and the longissimus dorsi muscle was determined by the emission spectrometry method in inductively coupled argon plasma (ICP-OES) on an Optima 2000 DV spectrophotometer (PerkinElmer Instruments INC, Waltham, USA). Metabolites in the blood serum: glucose, total protein, triglycerides, total cholesterol, high-density lipoproteins, low-density lipoproteins, as well as iron were determined by spectrophotometric methods with a PRO-Bio spectrophotometer (Marcel) using Alpha Diagnostics reagents.

\section{Statistical analysis}

The obtained data was analysed statistically by means of the STATISTICA 6.0 PL computer software using one-way analysis of variance. The significance of differences between the feeding groups was evaluated with the Duncan test.

\section{Results}

In the fattening period $30-60 \mathrm{~kg}$, pigs fed a diet supplemented with L-carnitine and Fe from Fe-AA complex had higher $(p \leq 0.05)$ AGD than the fatteners of other two groups, whereas, feed conversion was $0.32 \mathrm{~kg}$ less $(p \leq 0.05)$ than control group and $0.21 \mathrm{~kg}$ less than the group of L-carnitine (Table $2)$. In the fattening period $60-100 \mathrm{~kg}$, as well as in the whole fattening period $(30-100 \mathrm{~kg}), \mathrm{ADG}$, ADFI and feed:gain ratio in all feeding groups were similar.

Carcass characteristics of fatteners are presented in Table 3. The pigs obtaining a L-carnitine $+\mathrm{Fe}$ (as Fe-AA complex) supplement, when compared to the control group and L-carnitine, were characterised by a better meatiness $(p \leq 0.05)$ and a higher weight of fatless ham, respectively at $4.5 \%$ $(p \leq 0.05)$ and $3.4 \%$. The pigs of L-carnitine+Fe group also had a slightly larger area of longissimus dorsi muscle and a slightly thinner backfat. The pigs fed a diet with L-carnitine+Fe had increased Fe concentration in the longissimus dorsi muscle of these animals $(p \leq 0.05)$. The carcass traits of pigs obtaining $100 \mathrm{mg}$ L-carnitine in $1 \mathrm{~kg}$ feed did not differ significantly when compared with the control group.

The effect of the applied supplements on metabolites in the blood serum is presented in Table 4. The supplementation of diet with L-carnitine and L-carnitine+Fe decreased the concentration of triglycerides (by $10.9 \%, p \leq 0.05$, and $15.6 \%$, $p \leq 0.05$, respectively), total cholesterol (by $10.3 \%$, $p \leq 0.05$, and $7.0 \%$, respectively), low-density lipoproteins (by $18.8 \%, p \leq 0.01$, and $16.3 \%, p \leq 0.01$, respectively) and glucose (by 3.9 and $12.3 \%$, respectively; non-significant differences). On the other hand, the concentration of high-density lipoproteins-in the blood serum of pigs fed L-carnitine and L-carnitine $+\mathrm{Fe}$ diets was higher $(p \leq 0.01)$ by 24.7 and $26.0 \%$, respectively when compared to the control group. The combination of L-carnitine $+\mathrm{Fe}$ supplementations increased the Fe concentration in the blood serum of these animals $(p \leq 0.05)$. 
Vol. 18 (2009): 27-34.

Table 2. Growth performance of pigs fed diets supplemented L-carnitine or L-carnitine and iron.

\begin{tabular}{|c|c|c|c|c|}
\hline \multirow{2}{*}{$\begin{array}{l}\text { Treatment }^{1} \\
\mathrm{~N}\end{array}$} & \multirow{2}{*}{$\frac{\text { Control }}{25}$} & \multirow{2}{*}{$\frac{\text { L-carnitine }}{25}$} & \multirow{2}{*}{$\frac{\text { L-carnitine }+\mathrm{Fe}}{25}$} & \multirow{2}{*}{ SEM } \\
\hline & & & & \\
\hline \multicolumn{5}{|c|}{ Grower phase (30 to $60 \mathrm{~kg}$ ) } \\
\hline Body weight (kg) & 30.0 & 30.0 & 30.0 & 0.262 \\
\hline $\mathrm{ADG}(\mathrm{kg})$ & $0.64^{b}$ & $0.66^{\mathrm{b}}$ & $0.72^{\mathrm{a}}$ & 0.046 \\
\hline ADFI (kg) & 1.96 & 1.97 & 1.96 & 0.186 \\
\hline Feed:gain & $3.14^{\mathrm{b}}$ & $3.03^{\mathrm{ab}}$ & $2.82^{\mathrm{a}}$ & 0.025 \\
\hline \multicolumn{5}{|c|}{ Finisher phase (60 to $100 \mathrm{~kg}$ ) } \\
\hline Body weight (kg) & 60.0 & 60.0 & 60.0 & 0.311 \\
\hline $\mathrm{ADG}(\mathrm{kg})$ & 0.76 & 0.76 & 0.71 & 0.062 \\
\hline ADFI (kg) & 2.66 & 2.72 & 2.53 & 0.228 \\
\hline Feed:gain & 3.54 & 3.62 & 3.67 & 0.023 \\
\hline \multicolumn{5}{|c|}{ Overall (30 to $100 \mathrm{~kg})$} \\
\hline $\mathrm{ADG}(\mathrm{kg})$ & 0.70 & 0.71 & 0.71 & 0.053 \\
\hline ADFI (kg) & 2.31 & 2.35 & 2.24 & 0.242 \\
\hline Feed:gain & 3.34 & 3.30 & 3.20 & 0.028 \\
\hline
\end{tabular}

${ }^{1}$ In each treatment, basal diet contained $85 \mathrm{mg} / \mathrm{kg}$ of Fe from mineral premix. L-carnitine supplementation was $100 \mathrm{mg} / \mathrm{kg}$, and Fe supplementation $60 \mathrm{mg} / \mathrm{kg}$ from $\mathrm{Fe}$-amino acid complex.

a,b means marked with different small letters are significantly different, $\mathrm{p} \leq 0.05$

${ }^{\mathrm{c}}$ Standard error of the mean

Table 3. Carcass characteristics of pigs fed diets supplemented L-carnitine or L-carnitine and iron.

\begin{tabular}{|c|c|c|c|c|}
\hline \multirow{2}{*}{$\begin{array}{l}\text { Treatment } \\
\mathrm{N}\end{array}$} & Control & L-carnitine & L-carnitine $+\mathrm{Fe}$ & \multirow{2}{*}{$\mathrm{SEM}^{\mathrm{c}}$} \\
\hline & 25 & 25 & 25 & \\
\hline Slaughter weight (kg) & 100 & 100 & 100 & 0.34 \\
\hline Carcass length $(\mathrm{cm})$ & 82.8 & 81.4 & 85.0 & 0.85 \\
\hline Dressing percentage & 78.3 & 80.4 & 78.7 & 0.37 \\
\hline Meat in right carcass side $(\mathrm{kg})$ & 21.12 & 21.17 & 21.93 & 0.193 \\
\hline Fatless ham weight (kg) & $8.73^{b}$ & $8.92^{\mathrm{ab}}$ & $9.12^{\mathrm{a}}$ & 0.094 \\
\hline Longissimus muscle weight (kg) & 4.30 & 4.13 & 4.00 & 0.054 \\
\hline Longissimus muscle area $\left(\mathrm{cm}^{2}\right)$ & 53.2 & 51.4 & 54.9 & 0.99 \\
\hline \multicolumn{5}{|l|}{ Backfat thickness (cm) } \\
\hline - above shoulder blade & 3.40 & 3.33 & 3.28 & 0.132 \\
\hline - on the back & 2.02 & 1.87 & 1.91 & 0.057 \\
\hline Percentage lean & $56.0^{\mathrm{b}}$ & $56.8^{b}$ & $58.5^{\mathrm{a}}$ & 0.66 \\
\hline Fe in longissimus muscle $(\mathrm{mg} / \mathrm{kg})$ & $5.72^{\mathrm{b}}$ & $5.81^{\mathrm{b}}$ & $6.44^{\mathrm{a}}$ & 0.112 \\
\hline
\end{tabular}

${ }^{\mathrm{a}, \mathrm{b}}$ means marked with different small letters are significantly different, $\mathrm{p} \leq 0.05$

${ }^{\mathrm{c}}$ Standard error of the mean 
Pietruszka, A. et al. Effects of L-carnitine and iron on pig's traits

Table 4. Serum metabolites of pigs fed diets supplemented L-carnitine or L-carnitine and iron.

\begin{tabular}{|c|c|c|c|c|}
\hline Treatment & Control & L-carnitine & L-carnitine $+\mathrm{Fe}$ & \multirow{2}{*}{ SEM } \\
\hline $\mathrm{N}$ & 25 & 25 & 25 & \\
\hline Glucose (mmol/L) & 8.26 & 7.94 & 7.24 & 0.159 \\
\hline Total protein $(\mathrm{g} / \mathrm{L})$ & 75.6 & 76.6 & 78.2 & 0.49 \\
\hline Triglycerides (mmol/L) & $0.64^{\mathrm{b}}$ & $0.57^{\mathrm{a}}$ & $0.54^{\mathrm{a}}$ & 0.014 \\
\hline Total cholesterol $(\mathrm{mmol} / \mathrm{L})$ & $3.01^{\mathrm{b}}$ & $2.70^{\mathrm{a}}$ & $2.80^{\mathrm{ab}}$ & 0.036 \\
\hline High-density lipoproteins (mmol/L) & $0.73^{\mathrm{B}}$ & $0.91^{\mathrm{A}}$ & $0.92^{\mathrm{A}}$ & 0.016 \\
\hline Low-density lipoproteins (mmol/L) & $2.02^{\mathrm{B}}$ & $1.64^{\mathrm{A}}$ & $1.69^{\mathrm{A}}$ & 0.016 \\
\hline $\mathrm{Fe}(\mu \mathrm{mol} / \mathrm{L})$ & $15.7^{\mathrm{b}}$ & $14.8^{b}$ & $21.5^{\mathrm{a}}$ & 0.79 \\
\hline
\end{tabular}

$\mathrm{A}, \mathrm{B}$ means marked with different big letters are significantly different, $p \leq 0.01$;

${ }^{\mathrm{a}, \mathrm{b}}$ means marked with different small letters are significantly different, $p \leq 0.05$

${ }^{\mathrm{c}}$ Standard error of the mean

\section{Discussion}

In piglets and growing pigs, L-carnitine supplementation led to a reduction in body fat and an increase in body protein (Heo et al. 2000, Owen et al. 2001a, $2001 \mathrm{~b})$. This effect is due to an enhanced rate of $\beta$-oxidation of long-chain fatty acids. On the other hand, Owen et al. (2001a, 2001b) failed to detect an effect of supplementing 50 or 125 ppm L-carnitine on growth performance of growing pigs. In other studies it was shown that pigs fed a diet supplemented with 50 ppm L-carnitine had a higher daily gain, better feed conversion, better carcass meatiness and thinner backfat (Rekiel and Zackiewicz 2004). However, in our study, a supplement of $100 \mathrm{mg} / \mathrm{kg}$ L-carnitine to the pigs' diet did not have any effect both on the daily gains and feed conversion and the carcass traits. Similar results were obtained by Han and Thacker (2006) who used a 50 ppm L-carnitine supplement to the diet of finishing pigs. In our study the supplementation of L-carnitine had no effect on the quality of pork carcasses (non-significant statistical differences), however the pig carcasses of fatteners from the L-carnitine group characterised slightly thinner backfat (8\%) and slightly higher meatiness in comparison with control groups.

L-carnitine supplementation, by promoting $\beta$-oxidation of fatty acids, lowered the synthesis of very low-density lipoproteins and decreased the concentrations of triglycerides and total cholesterol (Maccari et al. 1987). In the presented study, and in those of Grela et al. (2005), it was also shown that L-carnitine decreased the concentration of triglycerides, cholesterol and low-density lipoproteins, while it increased that of high-density lipoproteins in the blood serum. On the other hand, it was found in other studies that L-carnitine did not differentiate the concentration of triglycerides and cholesterol in the blood plasma of piglets and pregnant sows when compared to control animals (Birkenfeld et al. 2006, Doberenz et al. 2006).

Woodworth et al. (2002) and Doberenz et al. (2006) showed that dietary carnitine reduced the concentrations of insulin and glucose in blood plasma, suggesting an enhanced glucose tolerance. In our study only a slight decrease was observed (statistically non-significant) in the concentration of glucose in the blood serum of fatteners obtaining the L-carnitine supplement in their diet. 


\section{AGRICULTURAL AND FOOD SCIENCE}

Vol. 18 (2009): 27-34.

The results of the presented study show that a supplement of $85 \mathrm{mg} / \mathrm{kg} \mathrm{Fe}$ (from premix) to the basal diet (in accordance with NRC, 1998) can be insufficient for growing pigs. An increase of its level by $60 \mathrm{mg} / \mathrm{kg} \mathrm{Fe}$ in the diet raised daily gains and feed conversion in pigs in the 30-60 kg body weight fattening period, while it did not have any effect on growth performance in the finishing pigs. Rincker et al. (2004) observed a linear increase in ADG as supplemental Fe increased from 0 to $150 \mathrm{ppm}$ in nursery pigs. On the other hand, Dove and Haydon (1991) failed to detect an effect of supplementing 50 to $300 \mathrm{ppm}$ Fe on growth performance of nursery pigs. Daily gains and feed conversion did not depend on 30 to $120 \mathrm{ppm} \mathrm{Fe}$ in the pig diet either (Yu et al. 2000, Saddoris et al. 2003). Apple et al. (2007) found that 50 to $150 \mathrm{ppm}$ Fe supplement in the grower and finisher diet increased the daily gains of growing pigs (55-68 kg BW), while not having any effect on growth performance in the finishing pigs. On the other hand, Liao et al. (2005) found a rise of growth performance in 50 to $100 \mathrm{~kg}$ $\mathrm{BW}$ pigs obtaining the chelated $\mathrm{Fe}(1 \mathrm{~g} / \mathrm{kg}$ diet $)$.

Very little information is available concerning the effects of dietary $\mathrm{Fe}$ on pork carcass characteristics. Saddoris et al. (2003) observed that supplementing pig diets with 90 ppm Fe did not affect average backfat depth and longissimus muscle area, whereas Apple et al. (2007) observed a linear increase in $10^{\text {th }}$-rib fat depth as supplemental Fe from 50 to $150 \mathrm{ppm}$ in diets. Our study showed a favourable effect of L-carnitine+Fe (as Fe-AA complex) supplement on the quality of pork carcasses. They were characterised by a higher lean percentage, larger fatless ham weight as well as by slightly thinner backfat when compared to control group pigs that obtained $100 \mathrm{mg} / \mathrm{kg}$ L-carnitine in their diet.

It was shown that the diet supplement of $\mathrm{Fe}$ increased the Fe concentration in the blood serum of nursery pigs (Rincker et al. 2004), while the supplement of chelated iron increased the Fe concentration in the longissimus dorsi muscle (Liao et al. 2005). Similar results were also shown in our study.

\section{Conclusions}

The results of the presented study show that a supplement of $100 \mathrm{ppm}$ L-carnitine to the diet does not have any effect on the growth performance of growing and finishing pigs and the carcass traits, while it decreases the concentration of lipids in blood. The combination of L-carnitine+Fe supplementations increased the growth performance of growing pigs and had a favourable effect on the carcass meatiness traits.

\section{References}

AOAC 1995. Official methods of analysis (6th ed.). Association of Official Analytical Chemists. Arlington, Virginia.

Apple, J.K., Wallis-Phelps, W.A., Maxwell, C.V., Rakes, L.K., Sawyer, J.T., Hutchison, S. \& Fakler, T.M. 2007. Effects of supplemental iron on finishing swine performance, carcass characteristics, and pork quality during retail display. Journal of Animal Science 85: 737-745.

Birkenfeld, C., Doberenz, J., Kluge, H. \& Eder, K. 2006. Effect of L-carnitine supplementation of sows on L-carnitine status, body composition and concentrations of lipids in liver and plasma of their piglets at birth and during the suckling period. Animal Feed Science and Technology 129: 23-38.

Doberenz, J., Birkenfeld, C., Kluge, H. \& Eder, K. 2006. Effects of L-carnitine supplementation in pregnant sows on plasma concentrations of insulin-like growth factors, various hormones and metabolites and chorion characteristics. Journal of Animal Physiology and Animal Nutrition 90: 487-499.

Dove, C. R. \& Haydon, K.D. 1991. The effect of copper addition to diets with various iron levels on the performance and haematology of weanling swine. Journal of Animal Science 69: 2013-2019.

Eder, K., Ramanau, A. \& Kluge, H. 2001. Effect of L-carnitine supplementation on performance parameters in gilts and sows. Journal of Animal Physiology and Animal Nutrition 85: 73-80.

Grela, E.R, Czech, A. \& Chachaj, R. 2005. Effect of Lcarnitine diets on performance and blood metabolites in sows. Journal of Animal and Feed Sciences 14 (Suppl. 1): 349-352.

Han, Y.K. \& Thacker, P.A. 2006. Effects of L-carnitine, selenium-enriched yeast, Jujube fruit and Hwangto (Red clay) supplementation on performance and carcass measurements of finishing pigs. Asian - Australian Journal of Animal Sciences 19: 217-223.

Heo, K., Odle, J., Han, I.K., Cho, W., Seo, S., Van Heugten, E. \& Pilkington, D.H. 2000. Dietary L-carnitine improves 


\section{AGRICULTURAL AND FOOD SCIENCE}

Pietruszka, A. et al. Effects of L-carnitine and iron on pig's traits

nitrogen utilization in growing pigs fed low energy, fatcontaining diets. Journal of Nutrition 130: 1809-1814.

Hoppel, C. 2003. The role of carnitine in normal and altered fatty acid metabolism. American Journal of Kidney Diseases 41 (Suppl.): 4-12.

Jacobs, S. 2002. Practical experiences with L-carnitine. Lohman Information 26: 1 - 4.

Jacyno, E., Kołodziej, A., Kamyczek, M., Kawęcka, M., Dziadek, K. \& Pietruszka, A. 2007. Effect of L-carnitine supplementation on boar semen quality. Acta Veterinaria Brno 76: 595-600.

Liao, Ch.W., Su, T.M., Liu, Ch.F., Chen, W.S. \& Lee, M.L. 2005. Effects of supplementing dietary vitamin E and chelated iron on the pork quality of TLRI Black Pig No. 1. Journal of Taiwan Livestock Research 38: 37-45.

Lipiński, K. 2007. Iron in pigs feeding. Trzoda Chlewna 1: 64-69.

Maccari, F., Arseni, A., Chiodi, P., Ramacci, M.T., Angelucci, L. \& Hulsmann, W.C. 1987. L-carnitine effect on plasma lipoproteins of hyperlipidemic fat-loaded rats. Lipids 22: 1005-1008.

NRC 1998. National Research Council. Nutrient Requirements of Swine (10 ${ }^{\text {th }}$ ed.). National Academy Press: Washington, DC: 110-123.

O'Sullivan, M.G., Byrne, D.V., Nielsen, J.H., Andersen, H.J. \& Martens M. 2003. Sensory and chemical assessment of pork supplemented with iron and vitamin E. Meat Science 64: 175-189.

Owen, K.Q., Ji, H., Maxwell, C.V., Nelssen, J.L., Goodband, R.D., Tokach, M.D., Tremblay, G.C. \& Koo, I.S. 2001a. Dietary L-carnitine suppresses mitochondrial branchedchain keto acid dehydrogenase activity and enhances protein accretion and carcass characteristics of swine. Journal of Animal Science 79: 3104-3112.

Owen, K.Q., Nelssen, J.L., Goodband, R.D., Tokach, M.D. \& Friesen, K.G. 2001b. Effect of dietary L-carnitine on growth performance and body composition in nursery and growing-finishing pigs. Journal of Animal Science 79: 1509-1515.

Ramanau, A., Kluge, H., Spilke, J. \& Eder, K. 2004. Supplementation of sows with L-carnitine during pregnancy and lactation improves growth of the piglets during the suckling period through increased milk production. Journal of Nutrition 134: 86-92.

Rekiel, A. \& Zackiewicz, U. 2004. Production results of fatteners fed a diet supplemented with L-carnitine. Annals of Animal Science (Suppl. 2): 181-185.

Rincker, M.J., Hill, G.M., Link, J.E. \& Rowntree, J.E. 2004. Effects of dietary iron supplementation on growth performance, haematological status, and whole-body mineral concentrations of nursery pigs. Journal of Animal Science 82: 3189-3197.

Saddoris, K.L., Crenshaw, T.D., Claus, J.R. \& Fakler T.M. 2003. Growth performance, carcass characteristic, and pork colour in finishing pigs fed two sources of supplemental iron. Journal of Animal Science 81 (Suppl. 2): 69 (abstract).

Vaz, F.M. \& Wanders, R.J. 2002. Carnitine biosynthesis in mammals. Biochemical Journal 361: 417-429.

Währner, M., Geyer, M., Hallfarth, G. \& Hühn, U. 2004. Der einfluss von zulagen einer vitaminemulsion mit L-Carnitin auf die spermaeigenschaften von besamungsebern. Zuchtungskunde 76: 196-207.

Woodworth, J.C., Tokach, M.D., Nelssen, J.L., Goodband, R.D., Dritz, S.S., Koo, S.I., Minton, J.E. \& Owen, K.Q. 2002. Influence of dietary carnitine/or chromium on blood parameters of gestating sows. Swine Day 2002, Report of Progress 897: 23-47.

Yu, B., Huang, W.J. \& Chiou, W.S. 2000. Bioavailability of iron from amino acid complex in weanling pigs. Animal Feed Science and Technology 86: 39-52. 